\title{
Warthin-Like Papillary Carcinoma of the Thyroid: A Case Series and Review of the Literature
}

\author{
Tiroidin Warthin-Benzeri Papiller Karsinomu: \\ Olgu Serisi ve Literatür Derlemesi
}

\author{
Ayça ERŞEN ${ }^{1}$, Merih Güray DURAK ${ }^{1}$, Tülay CANDA ${ }^{1}$, Ali İbrahim SEVINÇ², Serdar SAYDAM², \\ Mehmet Ali KOÇDOR ${ }^{2}$
}

Department of 'Pathology and ' ${ }^{2}$ General Surgery, Dokuz Eylül University Faculty of Medicine, IZMiR, TURKEY

\begin{abstract}
Warthin-like tumor of the thyroid is a recently described rare variant of thyroid papillary carcinoma. The distinguishing histological feature of this variant is papillary foldings lined by oncocytic neoplastic cells with clear nuclei and nuclear pseudoinclusions, accompanied by prominent lymphocytic infiltrate in the papillary stalks. Its prognosis has been reported to be almost similar to conventional papillary carcinoma. In this case series, we report four cases with Warthin-like papillary carcinoma of the thyroid, diagnosed at Dokuz Eylul University Faculty of Medicine Department of Pathology in 2008 and 2009. Three patients were female. The mean patient age was 39 years (range, 20-56) and the mean tumor size was $1.7 \mathrm{~cm}$ (range, 0.9-2.0 cm). All of the cases had lymphocytic thyroiditis in the background. None of the tumors showed lymphovascular invasion. The patients are free of any recurrence and/or distant metastasis with a mean follow-up of 25 months. This rare variant of thyroid papillary carcinoma with distinct histopathological features should be indicated in pathology reports. Further studies and long-term follow-up of patients are needed to highlight the biological behavior of this variant.
\end{abstract}

Key Words: Warthin tumor, Papillary carcinoma, Thyroid, Lymphocytic thyroiditis, Oncocytic change

\section{ÖZ}

Tiroidin Warthin-benzeri tümörü son dönemlerde tanımlanan, tiroid papiller karsinomunun nadir görülen bir varyantıdır. En önemli histolojik özelliği, nükleer psödoinklüzyonlar içeren berrak nukleuslu onkositik özellikte neoplastik hücrelerle döşeli, santral stromalarında belirgin lenfositik infiltrat bulunan papiller yapılardır. Prognozunun klasik papiller karsinom ile benzerlik gösterdiği bildirilmiştir. $\mathrm{Bu}$ olgu serisinde, Dokuz Eylül Üniversitesi Tip Fakültesi Patoloji Anabilim Dalı’nda 2008 ve 2009 yıllarında tanı almış dört Warthin-benzeri papiller karsinom olgusu sunulmuştur. Hastaların üçü kadın olup, ortalama yaş 39 (20-56 yaş), ortalama tümör boyutu $1.7 \mathrm{~cm}(0,9-2,0 \mathrm{~cm})$ idi. Olguların tümünde zeminde belirgin lenfositik tiroidit izlendi. Olguların hiçbirinde lenfovasküler invazyon görülmedi. Ortalama 25 aylık klinik ve radyolojik izlem sonucu hastaların hiçbirinde rekürrens ya da uzak metastaz saptanmadi. Tiroidin nadir görülen Warthin-benzeri papiller karsinomu, ayırdedici histopatolojik özelliklere sahip olup patoloji raporlarında belirtilmelidir. Bu varyantın biyolojik davranışını açığa çıkarabilmek için ileri çalışmalara ve uzun dönem hasta takiplerine ihtiyaç vardır.

Anahtar Sözcükler: Warthin tümörü, Papiller karsinom, Tiroid, Lenfositik tiroidit, Onkositik değişiklik

\section{INTRODUCTION}

Papillary carcinoma is the most common primary malignant neoplasm of the thyroid gland. According to the current classification of thyroid tumors by the World Health Organization (WHO), the major morphologic variants of papillary carcinoma are follicular, macrofollicular, oncocytic, clear cell, tall cell, columnar cell, diffuse sclerosing and solid variants (1). Warthin-like variant of papillary carcinoma is an uncommon variant that was first described by Apel et al. in 1995 (2). This morphologic variant has distinct features of papillary architecture with prominent lymphocytic stroma in fibrovascular cores,

(Turk Patoloji Derg 2013, 29:150-155)

Received : 05.04.2011 Accepted : 23.05.2011 resembling Warthin tumor of the salivary gland. The neoplastic cells lining the papillary folds have nuclear features of usual papillary carcinoma. Studies show that the overall and progression-free survival rates of these patients are similar to patients who have conventional papillary carcinoma (2-17). There is only one case of Warthin-like tumor of papillary carcinoma reported in the literature, who underwent anaplastic changes (14).

In this paper, we report four cases of Warthin-like tumor of papillary carcinoma, diagnosed at our institution in 2008 and 2009. The clinicopathological features of these patients are discussed, and the previously published reports are reviewed.

Correspondence: Merih Güray DURAK

Dokuz Eylül Üniversitesi Tip Fakültesi Patoloji Anabilim Dalı,

IZMİR, TURKEY

E-mail: merih.guray@deu.edu.tr Phone: +90 2324123419 


\section{CASE REPORTS}

Four cases diagnosed at Dokuz Eylul University Faculty of Medicine Department of Pathology in 2008 and 2009 were selected from the pathology archives of our institution. The clinical and follow-up information of these patients, including age, sex, size and localization of the tumor, and extent of surgery were obtained from the medical charts of the patients. Fine-needle aspiration (FNA) cytology was performed in three cases. The mean follow-up period of the patients was 25 months (range, 22-26 months).

The clinical features and the histopathological findings of the patients are summarized in Table I and Table II, respectively. The mean patient age was 39 years (range, 20-56). Three cases were female and one case was male. FNA cytology of two cases were diagnosed as suspicious for malignancy, and the other case as malignant (Figure 1). All of the cases underwent total thyroidectomy. Lymph node biopsy was performed in two cases (cases 1 and 3), in whom metastasis was not identified. Radionuclide therapy was performed in all patients. Postoperatively, each patient was clinically followed for local recurrence and/or distant metastases both by radiologic and scintigraphic methods. The mean follow-up period of the patients was 25 months (range, 22-26 months), and there was no sign of either local recurrence and/or distant metastases in any of the patients.

Multifocality was detected in three cases. The largest tumor size was $2 \mathrm{~cm}$ in three cases and $0.9 \mathrm{~cm}$ in one. One case showed invasion of the thyroid capsule and peripheral soft tissue. None of the tumors showed lymphovascular invasion at the time of diagnosis. Histologically, all of the tumors showed papillary architecture with lymphoplasmocytoid stroma in the papillary stalks (Figure 2). The neoplastic cells lining the papillary fronds had clear nuclei with a few nuclear pseudoinclusions, and abundant granular eosinophilic cytoplasm (Figure 3). All of the cases had lymphocytic thyroiditis in non-neoplastic areas (Figure 4).

\section{DISCUSSION}

Warthin-like papillary carcinoma is an uncommon variant of thyroid papillary carcinoma. Major histological features of these tumors are neoplastic cells with oncocytic changes and clear nuclei, lining the papillary fronds that have lymphocytic stroma in their stalks. The name comes from its close resemblance to Warthin tumor of the salivary gland. When Apel et al. first described the features of these tumors in 1995, they named it as "papillary Hurthle cell carcinoma of the thyroid with lymphocytic stroma - Warthin-like tumor of the thyroid" (2). After their description, approximately 95 cases have been reported in the literature, mostly as single case reports (2-16).

The mean age of patients with conventional papillary carcinoma is the mid 40's to early 50's (1). However, Warthin-like tumor variant of papillary carcinoma have been reported in a wide age range (19-85 years) in the literature (2-16). The mean age of our cases was 39 years (range, 20-56 years). Although some authors claim that this variant is mostly seen in elder patients, we believe it is more reasonable to expect these tumors at a broader age group than the conventional papillary carcinoma (11). Female/

Table I: Clinical features of the patients with Warthin-like papillary thyroid carcinoma

\begin{tabular}{|c|c|c|l|l|}
\hline Case (n) & Age / Sex & Tumor size $(\mathbf{c m})$ & \multicolumn{1}{|c|}{ Tumor localization } & \multicolumn{1}{|c|}{ FNA cytology } \\
\hline 1 & $20 / \mathrm{F}$ & 0.9 & Right lobe & Suspicious for malignancy \\
\hline 2 & $45 / \mathrm{F}$ & 2.0 & Right lobe & Malignant \\
\hline 3 & $36 / \mathrm{M}$ & 2.0 & Right lobe & Suspicious for malignancy \\
\hline 4 & $56 / \mathrm{F}$ & 2.0 & N/A & Absent \\
\hline
\end{tabular}

Abbreviation: FNA, fine-needle aspiration; F, female; M, male; N/A, not applicable

Table II: Histopathological features of the tumors

\begin{tabular}{|c|l|l|l|l|l|l|}
\hline Case $(\mathbf{n})$ & Multifocality & $\begin{array}{c}\text { Thyroid capsule } \\
\text { invasion }\end{array}$ & \multicolumn{1}{|c|}{ LVI } & $\begin{array}{c}\text { LN } \\
\text { metastasis }\end{array}$ & $\begin{array}{c}\text { Presence of } \\
\text { thyroiditis }\end{array}$ & $\begin{array}{c}\text { Accompanying papillary } \\
\text { carcinoma variant }\end{array}$ \\
\hline 1 & Present & Absent & Absent & Absent & Present & Follicular \\
\hline 2 & Present & Present & Absent & N/A & Present & Conventional \\
\hline 3 & Present & Absent & Absent & Absent & Present & Oncocytic \\
\hline 4 & Absent & Absent & Absent & N/A & Present & Conventional \\
\hline
\end{tabular}

Abbreviation: LVI, lymphovascular invasion; LN, lymph node; N/A, not applicable 


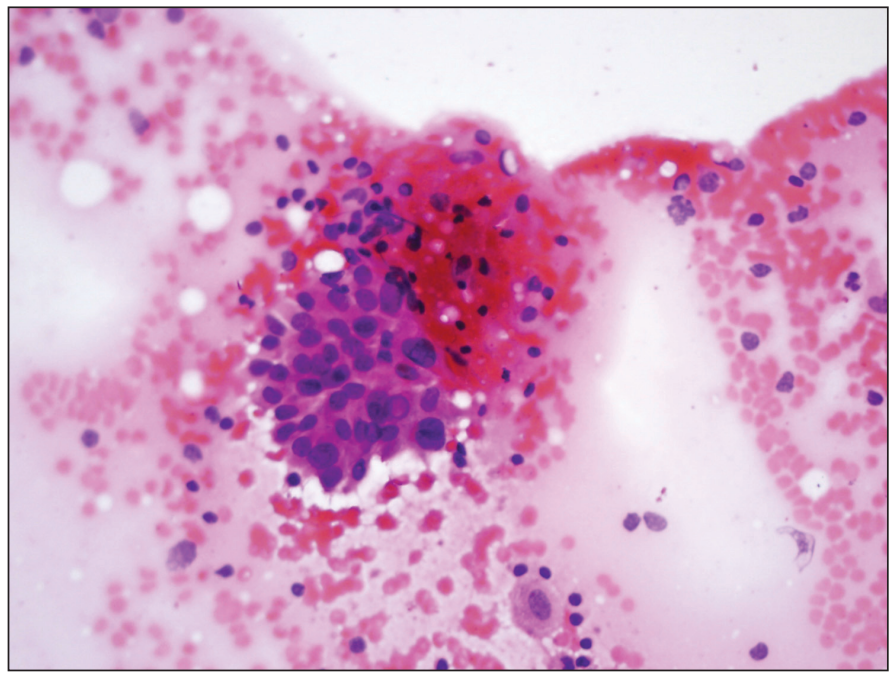

Figure 1: FNA cytology of case 2 showing pleomorphic neoplastic cells with eosinophilic cytoplasm, one of which has a pseudonuclear inclusion (H-E, $\mathrm{x} 400)$.

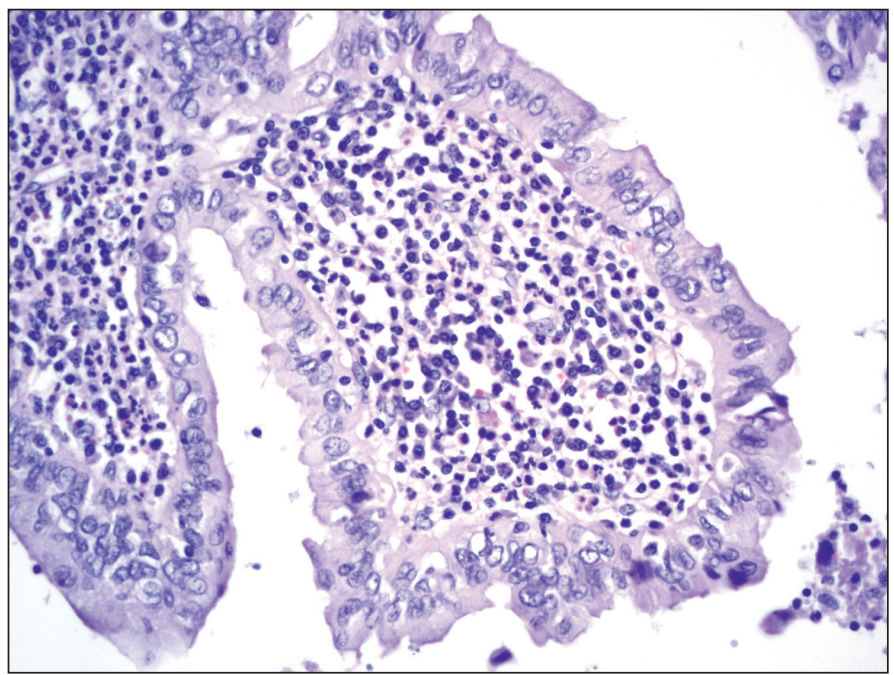

Figure 3: High power view of the same case as in Figure 2 showing neoplastic oncocytic cells with clear nuclei and a few nuclear grooves lining the papillary folds (H-E, x400).

male ratio is high in these tumors similar to the other papillary carcinoma variants. We had only one male patient as opposed to three females.

Previous case series of Warthin-like tumor variant of papillary carcinoma, together with the cases presented here, are summarized in Table III. It is emphasized that these tumors behave like usual papillary carcinomas with excellent long term overall survival (2-17). To the best of our knowledge, the only case of Warthin-like tumor variant of papillary carcinoma with anaplastic changes reported in the literature is a 74 year-old female (14). Having a recurrent nerve and lymph node involvement at the time

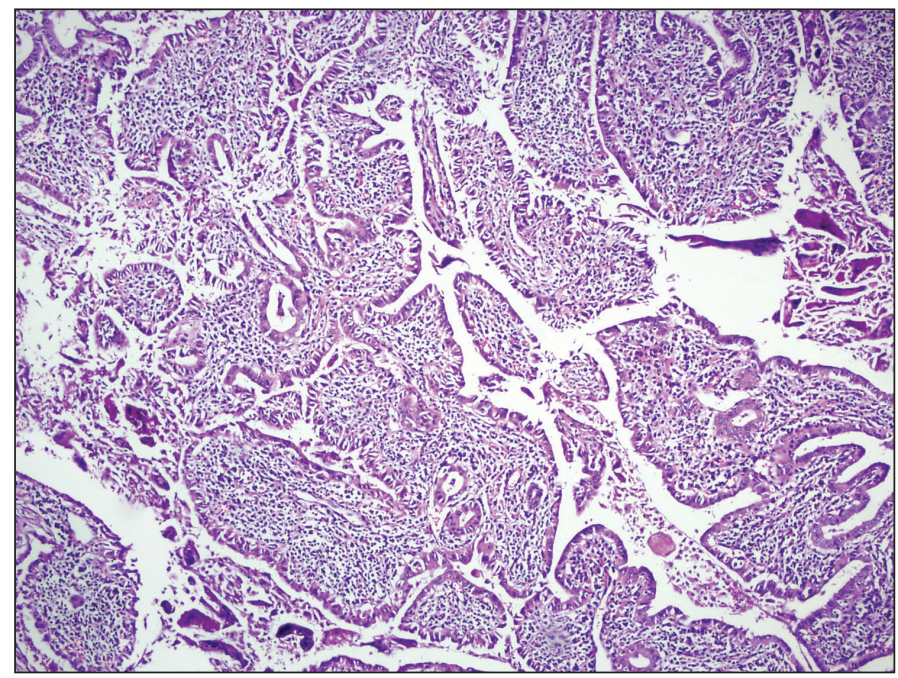

Figure 2: Histological appearance of case 4. There is prominent lymphocytic infiltrate in the stalks of the papillary folds (H-E, $\mathrm{x} 100)$.

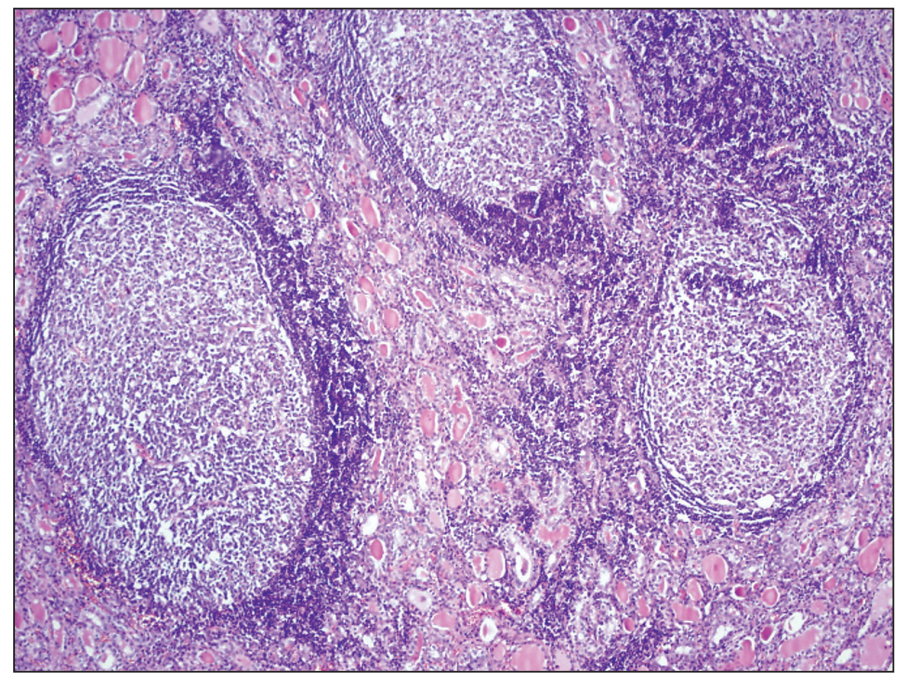

Figure 4: Lymphocytic thyroiditis in non-neoplastic areas of case 1 , accompanying the tumor (H-E, x100).

of diagnosis, by a delay of three years in her treatment, she died of the disease 18 months after the operation. One of our cases showed extrathyroidal extension, that is accepted as an unfavorable prognostic factor by the current WHO classification (1). With a mean follow-up period of 25 months, none of our cases showed any local recurrence and/ or distant metastasis. However, this time period is limited to make a realistic comment about the clinical behavior of these tumors.

The histologic appearance of Warthin-like tumor variant is similar to tall cell and columnar cell variants of papillary carcinoma that tend to show more aggressive clinical 
Table III: Previously reported case series of Warthin-like tumor of the thyroid

\begin{tabular}{|l|c|c|c|c|c|c|}
\hline \multicolumn{1}{|c|}{ Author } & $\begin{array}{c}\text { No. of } \\
\text { cases }\end{array}$ & $\begin{array}{c}\text { Mean age } \\
\text { (range) }\end{array}$ & F/M ratio & $\begin{array}{c}\text { Mean tm size } \\
(\mathbf{c m})(\mathbf{r a n g e})\end{array}$ & $\begin{array}{c}\text { Associated } \\
\text { thyroiditis }\end{array}$ & $\begin{array}{c}\text { LN } \\
\text { metastasis }\end{array}$ \\
\hline Apel et al.(2) & 13 & $40(26-63)$ & $12 / 1$ & $3.0(0.3-3.5)$ & 9 cases & 3 cases \\
\hline D’Antonio et al.(10) & 3 & $50(43-56)$ & $2 / 1$ & $1.4(1.3-1.5)$ & 3 cases & None \\
\hline Baloch \& LiVolsi(9) & 17 & $47(23-63)$ & $15 / 2$ & $2.4(0.4-3.0)$ & 17 cases & 3 cases \\
\hline Ludvikova et al.(11) & 12 & $64(45-85)$ & $11 / 1$ & $2.7(1.0-5.0)$ & 11 cases & 2 cases \\
\hline Present report & 4 & $39(20-56)$ & $3 / 1$ & $1.7(0.9-2.0)$ & 4 cases & None \\
\hline
\end{tabular}

Abbreviation: F, female; $\mathbf{M}$, male; $\mathbf{t m}$, tumor; $\mathbf{L N}$, lymph node

behavior than usual papillary carcinoma (18-23). The height of the oncocytic tumoral cells in the tall cell variant of papillary carcinoma is at least three times their width (1). The columnar cell variant, on the other hand, is composed of columnar cells containing cytoplasmic vacuoles, but they lack lymphocytic stroma (23). Various papillary carcinoma variants as well as some other histologic types of thyroid carcinoma, including medullary carcinoma may show oncocytic changes $(24,25)$. Besides, Hurthle cell carcinoma of the thyroid, which has worse prognosis than papillary carcinoma and its variants, may have pseudopapillary architecture histologically, although the nuclei lack usual papillary carcinoma features (26). The distinguishing feature of Warthin-like tumor of papillary carcinoma from all other histologic types and subtypes of thyroid carcinoma is the existence of lymphocytic stroma in the papillary stalks. This stroma may also contain follicles with germinal centers (12).

Some authors consider existence of lymphocytic stroma in a thyroid tumor as an indicator of favourable prognosis (9). According to these authors, tumor associated lymphocytes may play a role as a control mechanism. However, this claim has not been proven yet. Besides, lymphocytic infiltrate is commonly seen in thyroids with or without neoplasm (27). The case reports in the literature point out that lymphocytic thyroiditis or Hashimoto thyroiditis is an associating condition in most of the Warthin-like tumors (2-17). Recently, a simultaneous occurrence of Warthinlike papillary carcinoma and lymphoma in the background of Hashimoto thyroiditis has been reported by Panayiotides et al. (28). All of our cases had prominent lymphocytic thyroiditis in the non-neoplastic thyroid tissue. The role of intratumoral lymphocytes, whether as an autoimmune response impeding the spread of the tumor or providing a generous background for the development of the neoplasm, remains controversial (29-39).

FNA cytology findings of these tumors were first described by Yousef et al. (3) and Baloch et al. (40). The differential diagnosis of oncocytic variant of papillary carcinoma, conventional papillary carcinoma, Hurthle cell neoplasm arising in a background of lymphocytic thyroiditis, and Warthin-like papillary carcinoma can be challenging due to common findings in FNA. The pleomorphic oncocytic cells with nuclear features reminiscent of papillary carcinoma, admixed with inflammatory cells in the background should be warning in terms of Warthin-like papillary carcinoma $(3,5,40)$. Among our three cases who underwent FNA, cytological features supported malignancy in one, and were suspicious for malignancy in two cases. In evaluating FNA cytology, the most important thing is not to consider the prominent inflammatory cells in the background as "lymphocytic thyroidits", which may give rise to false negative diagnosis.

Due to the heterogeneity of thyroid papillary carcinomas, areas with features of usual or rare histologic variants may be seen in the same tumor. There are studies that report coexistent Warthin-like tumor variant of papillary carcinoma and other variants of thyroid carcinoma in the same patient. Some of these reported cases had worse prognosis due to the unfavourable prognosis of the accompanying tumors (26). In all of our cases, there was either a conventional, oncocytic or follicular variant of papillary carcinoma accompanying the tumor.

Multifocality is a frequent finding in papillary carcinomas and does not have any prognostic implication (1). Three of our cases were multifocal. One of the cases with multifocal tumor also had thyroid capsule and peripheral soft tissue invasion. Thyroid capsule invasion seems to be an unfavourable prognostic factor (1). However, it is not well known whether multifocality is a risk factor for the tumor to invade the thyroid capsule.

In conclusion, papillary carcinomas usually have perfect clinical outcome. Nevertheless, identifying the prognostically different subtypes of papillary carcinoma with distinct histopathological features is significant. We 
believe that Warthin-like tumor variant of papillary thyroid carcinoma, as well as other variants, should be indicated in pathology reports. Further studies and long-term follow-up of the patients are needed to highlight the biological and clinical behavior of these tumors.

\section{REFERENCES}

1. DeLellis RA, Lloyd RV, Heitz PU, Eng C. (Eds.): World Health Organization Classification of Tumours. Pathology and Genetics of Tumours of Endocrine Organs. Lyon, IARC Press, 2004

2. Apel RL, Asa SL, LiVolsi VA: Papillary Hürthle cell carcinoma with lymphocytic stroma. "Warthin-like tumor" of the thyroid. Am J Surg Pathol 1995, 19:810-814

3. Yousef O, Dichard A, Bocklage T: Aspiration cytology features of the warthin tumor-like variant of papillary thyroid carcinoma. A report of two cases. Acta Cytol 1997, 41:1361-1368

4. Vera-Sempere FJ, Prieto M, Camanas A: Warthin-like tumor of the thyroid: A papillary carcinoma with mitochondrion-rich cells and abundant lymphoid stroma. A case report. Pathol Res Pract 1998, 194:341-347

5. Fadda G, Mule A, Zannoni GF, Vincenzoni C, Ardito G, Capelli $A$ : Fine needle aspiration of a warthin-like thyroid tumor. Report of a case with differential diagnostic criteria vs. other lymphocyterich thyroid lesions. Acta Cytol 1998, 42:998-1002

6. Vasei M, Kumar PV, Malekhoseini SA, Kadivar M: Papillary Hürthle cell carcinoma (Warthin-like tumor) of the thyroid. Report of a case with fine needle aspiration findings. Acta Cytol 1998, 42:1437-1440

7. Imamura Y, Morishita T, Mori M, Maegawa M, Fukuda M, Konishi F: A case of Warthin-like tumor of the thyroid with Hashimoto's thyroiditis. J Jpn Society Clin Cytol 1999, 38:563-569

8. Sarkady E, Sapi Z, Toth V, Kiss S: Warthin-like tumor of the thyroid - a case report. Pathol Oncol Res 1999, 5:315-317

9. Baloch ZW, LiVolsi VA: Warthin-like papillary carcinoma of the thyroid. Arch Pathol Lab Med 2000, 124:1192-1195

10. D’Antonio A, De Chiara A, Santoro M, Chiappetta G, Losito NS: Warthin-like tumour of the thyroid gland: RET/PTC expression indicates it is a variant of papillary carcinoma. Histopathology 2000, 36:493-498

11. Ludvikova M, Ryska A, Korabecna M, Rydlova M, Michal M: Oncocytic papillary carcinoma with lymphoid stroma (Warthinlike tumour) of the thyroid: A distinct entity with favourable prognosis. Histopathology 2001, 39:17-24

12. Urano M, Abe M, Kuroda M, Mizoguchi Y, Horibe Y, Kasahara M, Tanaka K, Sudo K, Hirasawa Y: Warthin-like tumor variant of papillary thyroid carcinoma: Case report and literature review. Pathol Int 2001, 51:707-712

13. Anwar F: The phenotype of Hurthle and Warthin-like papillary thyroid carcinomas is distinct from classic papillary carcinoma as to the expression of retinoblastoma protein and E2F-1 transcription factor. Appl Immunohistochem Mol Morphol 2003, 11: 20-27
14. Lam KY, Lo CY, Wei WI: Warthin tumor-like variant of papillary thyroid carcinoma: A case with dedifferentiation (anaplastic changes) and aggressive biological behavior. Endocr Pathol 2005, 16:83-89

15. Montone KT, Baloch ZW, LiVolsi VA: The thyroid Hürthle (oncocytic) cell and its associated pathologic conditions. A surgical pathology and cytopathology review. Arch Pathol Lab Med 2008, 132:1241-1250

16. Kim HH, Myssiorek D, Heller KS, Zahurullah F, Bhuiya T: Warthin-like tumor of the thyroid gland: An uncommon variant of papillary thyroid cancer. Ear Nose Throat J 2006, 85:56-59

17. Chan JKC: Tumors of the thyroid and parathyroid glands. In Fletcher CDM. (Ed): Diagnostic Histopathology of Tumors. 3rd ed., Philadelphia, Elsevier Churchill Livingstone, 2007, 997-1015

18. Hawk WA, Hazard JB: The many appearances of papillary carcinoma of the thyroid. Cleve Clin Q 1976, 43:207-215

19. Ozaki O, Ito K, Mimura T, Sugino K, Hosoda Y: Papillary carcinoma of the thyroid. Tall-cell variant with extensive lymphocyte infiltration. Am J Surg Pathol 1996, 20:695-698

20. Ruter A, Nishiyama R, Lennquist S: Tall-cell variant of papillary thyroid cancer: Disregarded entity? World J Surg 1997, 21:15-20

21. Bocklage T, DiTomasso JP, Ramzy I, Ostrowski ML: Tall cell variant of papillary thyroid carcinoma: Cytologic features and differential diagnostic considerations. Diagn Cytopathol 1997, 17:25-29

22. Merino MJ, Monteagudo C: Tall cell carcinoma of the thyroid: An aggressive variant of papillary cancer. Pathol Case Rev 1997, 2:196-199

23. Mizukami Y, Nonomura A, Mishigishi T, Noguchi M, Nakamura $S$, Hashimoto T: Columnar cell carcinoma of the thyroid gland. A case report and review of the literature. Hum Pathol 1994, 25:1098-1101

24. Tallini G: Oncocytic tumours. Virchows Arch 1998, 433:5-12

25. Berho M, Suster S: The oncocytic variant of papillary carcinoma of the thyroid: A clinicopathologic study of 15 cases. Hum Pathol 1997, 28:47-53

26. Mai KT, Thomas J, Yazdi HM, Commons AS, Lamba M, Stinson $A W$ : Pathologic study and clinical significance of Hurthle cell papillary thyroid carcinoma. Appl Immunohistochem Mol Morphol 2004, 12:329-337

27. Williams ED, Doniach I: The post-mortem incidence of focal thyroiditis. J Pathol Bacteriol 1962, 83:255-264

28. Panayiotides IG, Foukas PG, Meristoudis C, Zourla AP, Peros G, Karakitsos P: Simultaneous occurrence of Warthin-like papillary carcinoma and lymphoma of the mucosa associated lymphoid tissue in Hashimoto thyroiditis. J Clin Pathol 2010, 63:662-663

29. Dailey M, Lindsay S, Skahen R: Relation of thyroid neoplasm to Hashimoto's disease of the thyroid gland. Arch Surg 1955, 70:291-297

30. Chesky VE, Helwig CA, Welch JW: Cancer of the thyroid associated with Hashimoto's disease: An analysis of 48 cases. Am Surg 1962, 28:678-685

31. Fukuda A, Hirohata T, Noguchi S, Ikeda M, Matsuo K, Yoshida $A$ : Risks for malignancies in patients with chronic thyroiditis: A long term follow-up study. Jpn J Cancer Res 1987, 78:1329-1334 
32. Carcangiu ML, Bianchi S, Savino D, Voynick IM, Rosai J: Follicular Hurthle cell tumors of the thyroid gland. Cancer 1991, 68:1944-1953

33. Li Volsi VA: Papillary neoplasms of the thyroid. Pathologic and prognostic features. Am J Clin Pathol 1992, 97:426-434

34. Okayasu I, Fujiwara M, Hara Y, Tanaka Y, Rose NR: Association of chronic lymphocytic thyroiditis and thyroid papillary carcinoma. Cancer 1995, 76:2312-2318

35. Matsubayashi S, Kawai K, Matsumoto Y, Mukuta T, Morita T, Hirai K, Matsuzuka F, Kakudoh K, Kuma K, Tamai H: The correlation between papillary thyroid carcinoma and lymphocytic infiltration in the thyroid gland. J Clin Endocrinol Metab 1995, 80:3421-3424

36. Mcleod MK, East ME, Burney RE, Harness JK, Thompson NW: Hashimoto's thyroiditis revisited: The association with thyroid cancer remains obscure. World J Surg 1988, 12:509-516
37. Schaffler A, Palitzsch KD, Seiffarth C, Hohne HM, Reidhammer FJ, Hofstadter F, Scholmerich J, Ruschoff J: Coexistent thyroiditis is associated with lower tumor stage in thyroid carcinoma. Eur J Clin Invest 1998, 28:838-844

38. Singh B, Shaha AR, Trivedi H, Carew JF, Poluri A, Shah JP: Coexistent Hashimoto's thyroiditis with papillary thyroid carcinoma: Impact on presentation, management and outcome. Surgery 1999, 126:1070-1077

39. Tamimi DM: The association between chronic lymphocytic thyroiditis and thyroid tumors. Int J Surg Pathol 2002, 10:141-146

40. Baloch ZW, LiVolsi VA: Fine-needle aspiration cytology of papillary Hurthle cell carcinoma with lymphocytic stroma "Warthin-like tumor" of the thyroid. Endocr Pathol 1998, 9: 317-323 